\title{
Problems and Suggestions for Private Equity Funds
}

\author{
Dongjun Zhao*, Jianwei Wan \\ Tianjin University of Commerce, Tianjin, China \\ Email: *496628464@qq.com
}

How to cite this paper: Zhao, D.J. and Wan, J.W. (2019) Problems and Suggestions for Private Equity Funds. Open Journal of Business and Management, 7, 1089-1094.

https://doi.org/10.4236/ojbm.2019.73074

Received: April 12, 2019

Accepted: May 3, 2019

Published: May 6, 2019

Copyright $\odot 2019$ by author(s) and Scientific Research Publishing Inc. This work is licensed under the Creative Commons Attribution International License (CC BY 4.0).

http://creativecommons.org/licenses/by/4.0/

\section{(c) (i) Open Access}

\begin{abstract}
With the rapid development of China's social economy, in order to meet the diverse investment needs and risk tolerance of investors, private equity investment funds have emerged in the market. This paper finds that while private equity funds continue to grow and develop, there are also many problems, such as the weak legal system of private equity funds, market manipulation risks, external environmental risks and regulatory defects. These defects not only infringe the interests of investors. It will also disrupt the stability of the entire capital market. This article will make some suggestions based on the fund itself, the formulation of laws and the behavior of the regulatory authorities, so that the development of private equity funds in China is more in line with the requirements of the market and laws and regulations.
\end{abstract}

\section{Keywords}

Private Equity Funds, Securities Investment, Insider Trading, Legal Supervision

\section{Introduction}

With the rapid development of China's capital market, private equity funds are also constantly expanding their market size, which has been favored by more and more investors. However, in my opinion, there are many shortcomings in private equity funds at this stage. Blind investment in private equity funds is not only a high-yield financial management method, but even bears excessive risks. This article will point out the shortcomings of private equity funds at this stage, and give specific solutions, in order to allow investors to have a clearer understanding of their investment targets and help regulators analyze the shortcomings of private equity funds at the current stage and promote further improvement of the regulatory system. 
This paper first analyzes the investment characteristics of private equity funds and private equity funds, so that readers have a general understanding of private equity funds, and then analyze the shortcomings of private equity funds at this stage. Finally, we will put forward relevant suggestions and suggestions for these shortcomings.

A private equity fund is an investment fund that is operated through a non-public, publicly funded society [1] [2] [3]. Compared with public funds, private equity funds are more able to meet the special investment needs of customers, and the investment methods are more flexible, so they are favored by many investors. Below we will analyze the investment characteristics of private equity funds:

1) The return on investment is very rich. Unlike debt investment, which earns several percentage points of interest on invested capital, equity investment takes the dividend of the company's income as the proportion of investment. Once the invested company successfully goes public, the profit of private equity investment fund may be several times or dozens of times.

2) Investment is accompanied by high risks. Equity investment usually needs to go through several years of investment cycle, and because of the investment in the development period or growth period of the enterprise, the development of the invested enterprise itself has a lot of risks; if the invested enterprise ended up in bankruptcy bleak, private equity funds may also be wiped out [4].

3) Investment can provide a full range of value-added services. Private equity investment in the target enterprises injected capital, but also injected advanced management experience and a variety of value-added services, which is the key factor to attract enterprises [5]. While meeting the financing needs of enterprises, private equity investment funds can help enterprises improve their operation and management ability, expand procurement or sales channels, facilitate the relationship between enterprises and local governments, and coordinate the relationship between enterprises and other enterprises in the industry. Comprehensive value-added services are the highlight and competitiveness of private equity investment funds. Although China's private equity fund has developed rapidly in recent years, some private equity fund managers are relatively weak in legal awareness and have some illegal behaviors such as insider trading and market manipulation. At the same time, the supervision system of private equity investment fund also has a variety of disadvantages, which need to be further strengthened and improved.

\section{Problems with Private Equity Funds in China}

1) The risk of a weak legal system in private equity funds

The important issue facing the development of private equity funds is its legality. So far, China has not defined the definition of private equity funds in legislation. On June 1, 2013, the "People's Republic of China Securities Investment Fund Law" was promulgated and implemented, and private equity funds began to be included in the scope of legal supervision [6]. Private equity funds have the 
advantages of flexible investment and strong competitiveness, as well as risks such as black-box management, self-interest, insider trading and market manipulation. Due to the lack of corresponding legal system and supervision, the level of private equity funds in China is not uniform. Private equity funds lacking legal basis are a double-edged sword for small and medium-sized investors with relatively weak self-protection: on the one hand, the flexible operation methods and successful operation levels of some private equity funds bring more investment opportunities to investors; on the other hand, small and medium investors generally lack self-protection ability and effective means. And because the institutional defects of China's securities market may lead to huge systemic risks in the industry, private equity funds are subject to legal norms.

2) Private equity funds have market manipulation risks

In the history of China's fund development, private equity funds have been the main force in the market to catch up and down, and its development faces a series of market manipulation risks [5]. Unordered competition in the market caused operational chaos. The private equity fund operating model is very flexible, either corporate or contractual, and can also be limited partnership. Therefore, it is difficult for securities regulators to conduct consistent supervision, which is easy to cause blind spots in supervision, leading to chaos in market competition. The main manifestations are: the lack of access threshold, the entry of the private equity market is out of control, even if there are relevant regulations. There are still many unqualified studios, consulting companies and asset management companies engaged in private equity investment business. Anyone can enter this industry. Various kinds of customer financing contracts are extremely irregular and do not comply with the "Contract Law of the People's Republic of China". Some organizations with poor qualifications have false promises, which has caused serious market confusion. With the development of the private equity market, its market influence has gradually increased, and the market manipulation risk has also increased invisibly, especially for the supervision of some stealth private equity funds.

3) External environmental risks of private equity funds

Due to the speed of China's economic development and higher fund returns, the securities market is developing very fast. When faced with the decline of the securities market, due to the lack of corresponding hedging tools, various negative chain reactions will occur, and even cause huge financial risks. At present, the homogenization of China's private equity fund securitization products is very serious. In addition, the function of China's capital market is still not perfect, and various institutional mechanisms are still not perfect. The external environment of private equity funds needs to be further optimized.

4) Private equity funds have certain regulatory risks

In the operation of private equity funds, although some fund companies have adopted the routines and methods of western state fund operation, there is no systematic credit risk in the development, but due to the lack of corresponding external supervision, fund managers deceive customers and manipulate the mar- 
ket. Behavior occurs from time to time. In China, the real development of private equity funds is actually after 1999, the rapid development of the capital market blinds the original authenticity of the capital market, and also hides the hidden dangers that may exist in the private equity market [7]. In addition, the varieties of China's capital market are relatively single, and a large number of funds are often accumulated in a single financial variety in the same way of operation and organization, which implies huge potential risks in the market. For the long-term operation of private equity funds, in addition to facing market risks, more direct credit and moral hazard, lack of laws, and increasingly fierce market competition, many fund managers have serious short-term behavior, fund operation and contract design are not only not Risk control mechanisms also lack external monitoring mechanisms.

\section{The Perfection of China's Private Equity Fund Supervision System}

Private equity funds have indeed played a positive role in increasing market liquidity in an active market and meeting the special investment needs of a small number of customers, but they have also aggravated market systemic risks and market volatility. Therefore, government departments must increase their supervision and reduce their negative impact, which is conducive to the stability and balanced development of the market. At present, China's focus on private equity fund supervision is mainly on the approval of private fund managers' qualifications, and thus restricts the fund investment ratio and investment direction to control investment risks. This traditional supervision method It is difficult to adapt to the flexibility and risk level of private equity investment. Therefore, while protecting the general investors, China should actively learn from foreign advanced experience, relax restrictions on private equity funds, clarify the basic ideas of private equity fund supervision, and escort the development of private equity funds. The following are some suggestions for improving the supervision of private equity investment funds:

1) The concept of private equity investment is gradually moving closer to value investment

Value investment theory believes that the price of securities has a tendency to move closer to its intrinsic value in the long run, so once the market price of the stock is undervalued and lower than its intrinsic value, the opportunity for investment appears. The value investment behavior of private equity funds is conducive to stabilizing the price of securities and is conducive to the efficient operation of the securities market.

2) Improve the self-regulatory principles of the industry

Private equity investment funds should regulate their own behavior and abide by the trading order and principles of the securities market [8]. The private equity fund manager shall, in accordance with the requirements of the association, conduct compliance reporting on the fund products and manage the investment 
assets in accordance with the agreement of the fund contract, actively perform the duty of diligence and responsibility, take the initiative to assume social responsibilities, and safeguard the legitimate rights and interests of investors.

3) Further improve the information disclosure system of private equity funds

In order to let investors know the operation of the fund in a timely manner and take corresponding measures to control their own risks when necessary, after the establishment of the private equity fund, it should disclose its investment status and financial status to investors on a regular basis. At the same time, the regulatory authorities should regularly review private fund investment reports and severely investigate and deal with private fund information disclosure violations.

4) Increase the punishment for market violations

The illegal investment behavior of private equity funds can easily lead to market systemic risks. Some fund managers obtain insider information through illegal means, and then use their own capital advantages to manipulate stock trading prices and disrupt market order [9]. Therefore, the regulatory authorities should increase the investigation and punishment of trading violations.

5) Improve the registration and filing system of private equity funds

In developed countries such as the United States, private equity funds are exempted from registration, but considering that China's securities market is not mature enough, and in order to facilitate the supervision of private equity investment behavior and control its investment risks, the amount of assets under management exceeds a certain scale and the number of investors. Exceeding a certain number of private equity funds, the regulatory authorities should require them to file with the relevant departments.

\section{Conclusion}

The healthy development of private equity investment funds requires the joint efforts of two entities. On the one hand, private fund managers should change their investment philosophy, try to avoid touching the red line of insider trading, and gradually move closer to value investment; on the other hand, the regulatory authorities should further standardize the private equity fund registration and filing system, improve the private equity fund information disclosure system, and increase penalties for market violations to strengthen the supervision of private equity investment funds. Scientifically handling the relationship between these two aspects is of great significance to the development of private equity investment funds in China.

\section{Conflicts of Interest}

The authors declare no conflicts of interest regarding the publication of this paper.

\section{References}

[1] Zhang, R. (2009) The Transformation of Overseas Private Equity Fund Supervision and Its Enlightenment. Securities Market Herald, No. 8, 18-22+50. 
[2] Chen, W. (2016) Development Risk and Supervision Strategy of Private Equity Funds in China. Research on Financial and Economic Issues, No. S2, 32-34.

[3] Wang, R. (2012) On the Construction of China's Private Equity Investment Fund Supervision System. Comparative Law Research, No. 1, 48-58.

[4] Ling, X., Chen, H. and Chen, U. (2002) Reflections on China's Private Equity Funds. Journal of Central University of Finance and Economics, No. 6, 37-39+60.

[5] Wang, L. (2007) China's Private Equity Market Is Gradually Active. China Science and Technology Investment, No. 2, 71-72.

[6] Dai, Q. (2004) A Preliminary Study on the Supervision System of Private Equity Funds in China. Hunan Social Sciences, No. 2, 95-97.

[7] Xiong, Q. (2004) Discussion on the Standardization Development of Private Equity Funds in China. Northern Economy and Trade, No. 1, 45-46.

[8] Cao, X. (2005) On the Regulation of Private Equity Fund Supervision. Theoretical Circles, No. 4, 90-91.

[9] Guo, W. (2009) The Development of American Private Equity Fund Regulations and Its Enlightenment. Global Law Review, 31, 90-98. 